\title{
PREDIKSI FINANCIAL DISTRESS PADA PT. BANK RAKYAT INDONESIA (Persero) TBK. SEBELUM DAN SEMASA PANDEMI COVID-19
}

\author{
Didi Rahmat \\ didirahmat18@gmail.com \\ STIE Indonesia Pontianak
}

\begin{abstract}
This study aims to see how the financial performance of PT. Bank Rakyat Indonesia (Persero) Tbk. studied from the Financial Distress approach. The data taken is from the period 2017 to 2019 (normal period) and 2020 (the period of the Covid-19 pandemic in Indonesia). Altman Z Score is used as an approach in data analysis by using five indicators, Working capital to total assets (WCTA), Retained earnings to total assets (RETA), Earnings before interest and taxes to total assets (EBITTA), Market Value of equity / Book value of debt (MVEBVD) and Sales / total assets (SATA). From the results of data analysis, it was found that before the Covid-19 pandemic the company was classified as healthy. Changes occurred during the Pandemic the company was in the Gray Area which meant there were financial problems.
\end{abstract}

Key Word: Financial Distress, WCTA, RETA, EBITTA, MVEBVD, SATA

\section{PENDAHULUAN}

Tidak bisa dipungkiri, pandemic Covid-19 di Indonesia memberikan dampak yang luar biasa terhadap seluruh sektor kehidupan, tentu saja tidak terkecuali di bidang ekonomi. Seluruh sektor ekonomi, baik mikro maupun makro juga menghadapi dampak yang besar dan merugikan. Beragam upaya pemerintah dilakukan dalam mengendalikan pandemic ini juga upaya mereduksi dampaknya seminimal mungkin.

Sebelum terjadinya pandemi, PT. Bank Rakyat Indonesia (Persero) Tbk. mencatatkan kinerja keuangan yang tergolong sangat baik jika di bandingkan dengan Bank BUMN lainnya. Dari tahun 2015 sampai dengan tahun 2018 indikator kinerja keuangan OPM, NPM, ROA, ROE, Total Asset Growth yang selalu berada diatas rata-rata kinerja keuangan Bank BUMN lainnya (Rahmat 2019). Demikian pula pada masa pandemi, sepanjang 2020 total aset yang dimiliki BRI Group mampu tumbuh 6,7 persen secara tahunan menjadi Rp1.511,3 triliun. Nilai ini menjadikan BRI sebagai satu-satunya BUMN dan bank milik negara yang asetnya tembus Rp1.500 triliun atau terbesar di Indonesia.

Rasio kredit bermasalah BRI atau Loan at Risk (LAR) hingga kuartal III/2020 mencapai 29,77 persen. Angka ini muncul karena BRI banyak melakukan program PEN, salah satunya restrukturisasi terhadap debitur UMKM. Meski angkanya naik dibanding periode setahun sebelumnya, tetapi pengelolaan LAR BRI tetap dikelola dengan bagus. Hal ini terjadi lantaran sejak beberapa tahun lalu BRI telah secara konsisten menaikkan rasio pencadangan dan kecukupan modal. Hingga kuartal III/2020, rasio kecukupan modal (Capital Adequacy Ratio/CAR) BRI tercatat sebesar 20,38 persen. Tingginya rasio kecukupan modal ini menunjukkan terjaganya kemampuan perusahaan untuk menghadapi berbagai potensi risiko di masa depan

Emiten BUMN perbankan PT Bank Rakyat Indonesia (Persero) Tbk. membukukan total laba bersih konsolidasian sebesar Rp18,65 triliun pada 2020. Berdasarkan laporan keuangannya yang dipublikasikan di Harian Bisnis Indonesia, Rabu (19/8/2020), perolehan laba bersih Rp18,65 triliun tersebut lebih rendah 45.65 persen year on year (yoy) dibandingkan dengan periode sama tahun 2019 sejumlah Rp34,37 triliun. Kondisi tersebut lantaran adanya tekanan di sisi pendapatan. Pendapatan bunga BBRI pada 2020 mencapai Rp116,93 triliun, turun 3,96 persen yoy dari Rp121,76 triliun pada 2019.

Sementara itu, kas neto yang digunakan untuk kegiatan investasi mencapai Rp116 triliun, naik drastis dari Rp5,19 triliun pada tahun sebelumnya. Total kas dan setara kas pada akhir 2020 sebesar Rp167,25 triliun, turun dari Rp236,91 triliun pada akhir 2019. Ekuitas BBRI (konsolidasi) mencapai Rp199,38 triliun pada akhir tahun lalu, 
turun dari Rp206,32 triliun pada tahun sebelumnya. Total liabilitas meningkat menjadi Rp1.311,89 triliun dari Rp1.207,97 triliun pada akhir 2019. Jadi memang harus diakui bahwa tahun 2020 merupakan tahun yang berat bagi Bank BRI (persero)Tbk.

\section{TINJAUAN TEORITIS}

\section{Financial Distress}

Financial distress atau kesulitan keuangan dapat diartikan sebagai ketidakmampuan perusahaan untuk membayar kewajiban keuangannya pada saat jatuh tempo yang menyebabkan kebangkrutan perusahaan (Darsono dan Ashari, 2011). Financial distress juga didefinisikan sebagai tahap penurunan kondisi keuangan yang terjadi sebelum kebangkrutan atau likuidasi (Platt dan Platt, 2002). Mc Cue (1991) dalam Atmini (2005) mendefinisikan financial distress sebagai arus kas negatif. Hofer (1980) dan Whitaker (1999) dalam Atmini (2005) mendefinisikan financial distress jika beberapa tahun perusahaan mengalami laba operasi negatif. John et al. dalam Atmini (2005) mendefinisikan financial distress jika melakukan pemberhentian tenaga kerja atau menghilangkan pembayaran dividen. Tirapat dan Nittayagasetwat (1999) dalam Atmini (2005) mengatakan bahwa perusahaan mengalami financial distress jika perusahaan menghentikan operasinya dan perusahaan mengalami pelanggaran teknis dalam hutang dan diprediksi akan mengalami kebangkrutan pada periode yang akan datang.

Kesulitan keuangan bisa digambarkan di antara dua titik ekstrim yaitu kesulitan likuiditas jangka pendek (yang paling ringan) sampai insolvency (yang paling parah). Kesulitan keuangan jangka pendek biasanya bersifat sementara, tetapi bisa berkembang menjadi parah. Pengelolaan kesulitan keuangan jangka pendek (tidak mampu membayar kewajiban pada saat jatuh tempo) yang tidak tepat akan menimbulkan permasalahan yang lebih besar yaitu menjadi tidak solvabel (jumlah utang lebih besar daripada jumlah aset) dan akhirnya mengalami kebangkrutan (Munawir, 2014).

Platt dan Platt (1991) dalam Widiyaningsih (2008) menyatakan kegunaan informasi jika suatu perusahaan mengalami financial distress adalah:

1. Dapat mempercepat tindakan manajemen untuk mencegah masalah sebelum terjadinya kebangkrutan.

2. Pihak manajemen dapat mengambil tindakan merger atau takeover agar perusahaan lebih mampu untuk membayar hutang dan mengelola perusahaan dengan baik.

3. Memberikan tanda peringatan awal adanya kebangkrutan pada masa yang akan datang.
Hanafi (2005) menyatakan bahwa hasil prediksi financial distress dan kepailitan perusahaan menjadi perhatian dari beberapa pihak. Pihak-pihak yang menggunakan model tersebut antara lain:

1. Kreditur

Hasil prediksi financial distress mempunyai relevansi terhadap institusi pemberi pinjaman, baik dalam memutuskan pemberian suatu pinjaman maupun menentukan kebijakan untuk mengawasi pinjaman yang telah diberikan.

2. Investor

Hasil prediksi financial distress dapat membantu investor ketika akan menilai kemungkinan masalah suatu perusahaan dalam melakukan pembayaran kembali pokok dan bunga.

3. Pembuat peraturan (pemerintah)

Pemerintah mempunyai tanggung jawab mengawasi kesanggupan membayar hutang dan menstabilkan perusahaan individu, hal ini menyebabkan perlunya suatu model yang aplikatif untuk mengetahui kesanggupan perusahaan membayar hutang dan menilai stabilitas perusahaan.

4. Auditor

Model prediksi financial distress dapat menjadi alat yang berguna bagi auditor dalam membuat penilaian going concern suatu perusahaan.

5. Manajemen

Apabila perusahaan mengalami kebangkrutan maka perusahaan akan menanggung biaya langsung (fee akuntan dan pengacara) dan biaya tidak langsung (kerugian penjualan atau kerugian paksaan akibat ketetapan pengadilan), sehingga dengan adanya model prediksi financial distress diharapkan perusahaan dapat menghindari kebangkrutan dan menghindari biaya langsung dan tidak langsung dari kebangkrutan.

Corporate Financial Distress Prediction sendiri adalah merupakan bidang ilmu yang penting dalam kajian keuangan (finance).

Diawal perkembangannya model yang digunakan dalam melakukan prediksi adalah probit model, Multiple discriminant analysis (MDA), univariate analysis, logistic model, dan lainnya (Beaver,1996; Altman ,1968; Altman, Haldeman, Narayanan, 1977; Martin, 1977; Ohlson, 1980). Dengan berkembangnya teknologi, terutama di bidang computer yang sudah mengadopsi teknologi Artificial Intelligence. Dengan kemampuan komputasi atas permasalahan yang bersifat non linier. Perkembangan teknologi komputer, mendukung semakin luasnya model dan alat analisis yang digunakan dalam CFD. Beberapa metode yang berbasis pada teknologi AI seperti Neural Network (NN), Genetic Algorithm, rough set theory casebased reasoning, support vector machine (Park, Han, 2002; Shin, Lee, Kim, 2005; Wu, Liang, Yang, 
2008; Lee, To, 2010; Shen, Et.all., 2011; Sun, He, Quarter 4 report PT. Bank Republik www.idx.co.id Li, 2011; Cao, Wan, Wang, 2011; Chaudhuri, De, Indonesia (Persero) Tbk. Tahun 2020 2011; Zhou, et.all, 2012). Annual report PT. Bank Republik www.idx.co.id Salah satu model yang bisa digunakan Indonesia (Persero) Tbk. Tahun 2019 dalam memprediksi financial distress adalah Model Annual report PT. Bank Republik www.idx.co.id Altman (Gunawan et al. 2017, Wulandari et al. 2014) Indonesia (Persero) Tbk. Tahun 2018

Altman (1968) menggunakan model step-wise Annual report PT. Bank Republik www.idx.co.id multivariate discriminant analysis (MDA) dalam Indonesia (Persero) Tbk. Tahun 2017 penelitiannya. Seperti regresi logistik, teknik statistika ini juga biasa digunakan untuk membuat model dimana variabel dependennya merupakan variabel kualitatif. Output dari teknik MDA adalah persamaan linear yang bisa membedakan antara dua keadaan variabel dependen.

Kelima rasio yang digunakan Altman dimasukkan ke dalam analisis MDA dan menghasilkan model sebagai berikut:

$\mathrm{Z}=1,2 \mathrm{X} 1+1,4 \mathrm{X} 2+3,3 \mathrm{X} 3+0,6 \mathrm{X} 4+0,988 \mathrm{X} 5$

Keterangan:

$\mathrm{X} 1=\quad$ Working capital to total asset (WCTA)

$\mathrm{X} 2=\quad$ Retained earnings to total asset (RETA)

$\mathrm{X} 3=\quad$ Earnings before interest and taxes to total asset (EBITTA)

$\mathrm{X} 4=\quad$ Market Value of equity /Book value of debt (MVEBVD)

$\mathrm{X} 5=\quad$ Sales $/$ total asset (SATA)

Altman menggunakan nilai cutoff 2,675 dan 1,81 . Artinya jika nilai $\mathrm{Z}$ yang diperoleh lebih dari 2,675, perusahaan diprediksi tidak mengalami Financial Distress dimasa depan. Perusahaan yang nilai Z-nya berada di antara 1,81 dan 2,675 berarti perusahaan itu berada dalam grey area, yaitu perusahaan mengalami masalah dalam keuangannya. Jika nilai skor berada di bawah 1.81 maka perusahaan memiliki potensi kebangkrutan.

\section{METODE PENELITIAN}

Yang menjadi unit analisis dalam penelitian ini adalah PT. Bank Rakyat Indonesia (Persero) Tbk. data yang di ambil merupakan data sekunder dengan teknik pengambilan data metode arsip. Data yang diambil secara daring pada portal Bursa Efek Indonesia (www.idx.co.id). Berikut data yang di kumpulkan:

Variabel dalam penelitian ini yaitu Model Altman. Indikator yang diteliti terdiri dari Working capital to total asset (WCTA), Retained earnings to total asset (RETA), Earnings before interest and taxes to total asset (EBITTA), Market Value of equity /Book value of debt (MVEBVD) dan Sales / total asset (SATA). Berikut adalah devinisi pengukuran indikatorindikator tersebut:

Working capital/total asset (WCTA) = (Aset Lancar - Hutang Lancar)/Total Aset, sesuai dengan yang digunakan dalam penelitian Cahyaningrum dan Haryanto (2012).

Retained Earnings/Total asset (RETA) = Laba ditahan/Total Aset, sesuai dengan penelitian Ardiyanto dan Prasetiono (2011).

Earnings before interest and taxes/total asset (EBITTA) = Pendapatan sebelum Bunga dan Pajak/Total Aset, sesuai dengan yang digunakan dalam penelitian Maryati dan Zulkarnain (2014).

Market value of equity/book value of total debt (MVEBVD) $=$ (harga saham $\mathrm{x} \Sigma$ saham beredar)/Total Hutang, sesuai dengan yang digunakan dalam penelitian Rismawati (2008).

Sales/Total asset $($ SATA $)=$ Penjualan/Total Aset, sesuai dengan Ardiyanto dan Prasetiono (2011).

Analisis data dilakukan dengan cara menghitung masing masing nilai indikator dan kemudian dimasukkan kedalam model Z Score Altman dengan nilai cutoff 2,675 dan 1,81. Artinya jika nilai $Z$ yang diperoleh lebih dari 2,675, perusahaan diprediksi tidak mengalami Financial Distress dimasa depan. Perusahaan yang nilai Z-nya berada di antara 1,81 dan 2,675 berarti perusahaan itu berada dalam grey area, yaitu perusahaan mengalami masalah dalam keuangannya. Hasil perhitungan juga di sajikan dalam bentuk grafik dan naratif dalam pengambilan kesimpulan.

Tabel 1

Pengumpulan Data

HASIL PENELITIAN DAN PEMBAHASAN

\begin{tabular}{ll}
\hline Uraian data & Sumber \\
\hline Quarter 1 report PT. Bank Republik & www.idx.co.id \\
Indonesia (Persero) Tbk. Tahun 2020 & \\
\hline Quarter 2 report PT. Bank Republik & www.idx.co.id \\
Indonesia (Persero) Tbk. Tahun 2020 & \\
\hline Quarter 3 report PT. Bank Republik & www.idx.co.id \\
Indonesia (Persero) Tbk. Tahun 2020 & \\
\hline
\end{tabular}

Indikator X1 Working capital to total asset (WCTA), hasil olah data memeprlihatkan perubahan negatif dari sebelum (2017-2019) dibandingkan dengan masa terjadinya pandemic (2020). Rasio perubahan ini sebear $-9,98 \%$ seperti tergambar pada grafik berikut: 


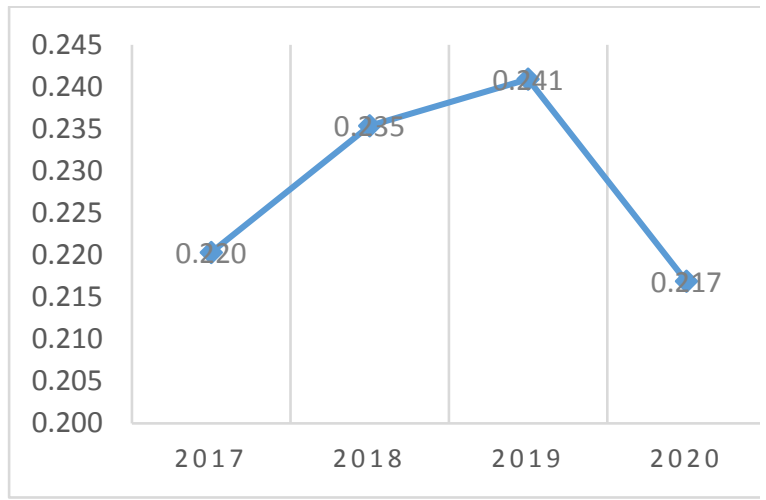

Grafik 1. X1 WCTA

Indikator X2 Retained earnings to total asset (RETA).

Hasil olah data menunjukkan perubahan negatif yang cukup besar yaitu $-49,1 \%$. Ini memberikan gambaran rasio perputaran pendapatan terhadap total asset yang menurun cukup besar seperti tergambar pada grafik berikut.

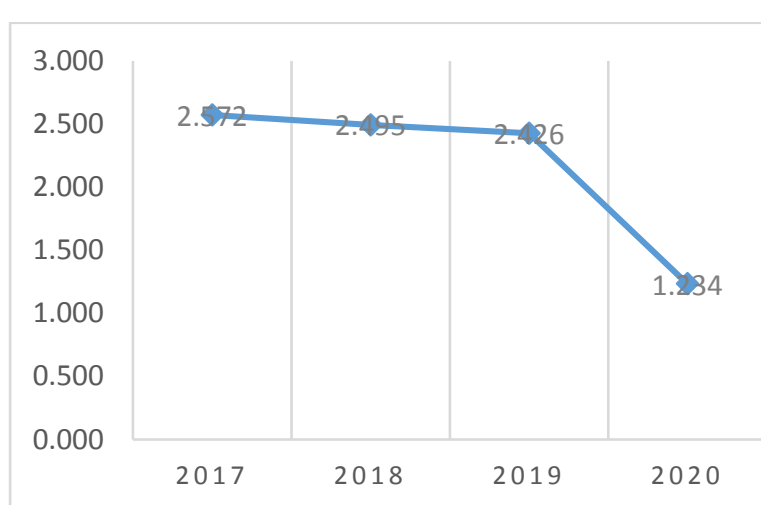

Grafik 2. X2 RETA

Indikator X3 Earnings before interest and taxes to total asset (EBITTA)

Sama halnya dengan indikator RETA, EBITTA juga mengalami penurunan yang besar. Penurunan pendapatan sebelum bunga dan pajak terhadap total asset menurun sebesar $-42,25 \%$. Grafik berikut memberikan gambaran penurunannya:

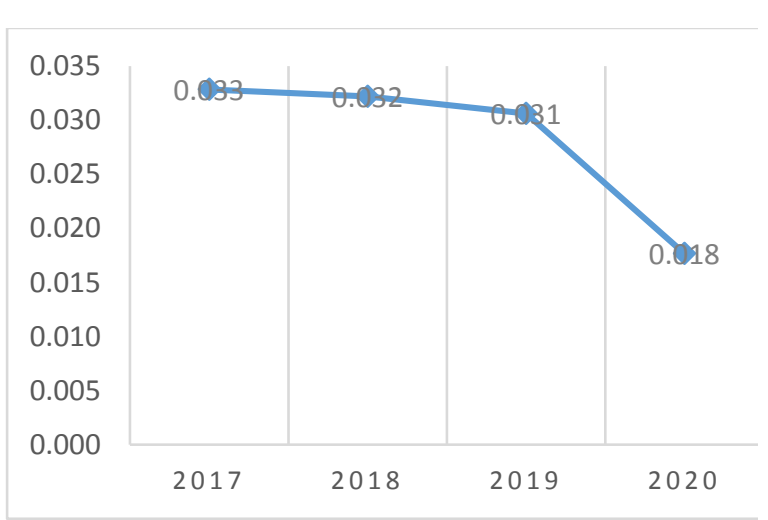

Grafik 3. X3 EBITTA
Indikator X4 Market Value of equity /Book value of debt (MVEBVD)

Tidak jauh berbeda dengan ketiga indikator sebelumnya, rasio penurunannya sebesar $-23,52 \%$. Meskipun secara parsial harga saham BBRI mengalami peningkatan namun jika dibandingkan kan dengan total hutang rasio ini menurun terutama di tahun 2020. Nilai saham rata-rata tahun 2019 mencapai Rp. 4.185,0 perlembar saham, dan tahun 2020 rata-rata pertahun Rp. 3.475,83,- per lembar saham.

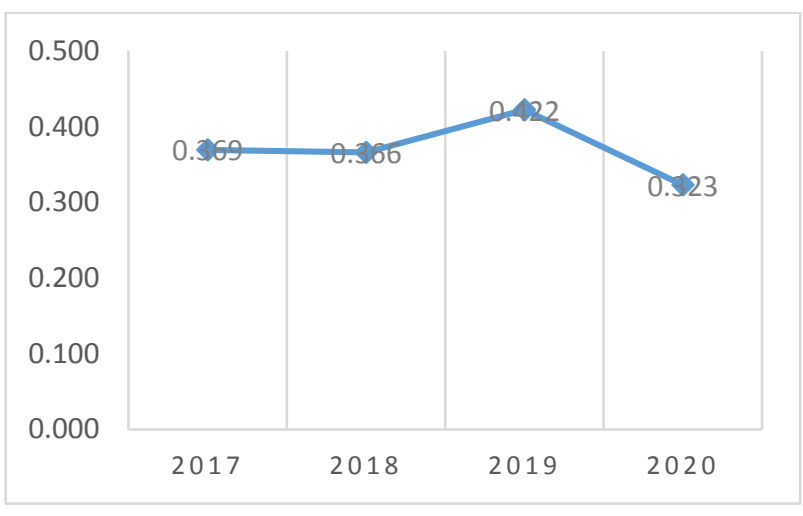

Grafik 4. X4 MVEBVD

Indikator X5 Sales / total asset (SATA)

Inikator ini juga mengalami penuruna semasa pandemic jika dibandingkan sebelumnya, penurunan yang terjadi sebesar $-13,19 \%$. Indikator ini menggambarkan kinerja total pendapatan dibandingkan dengan total asset pada tahun berjalan.

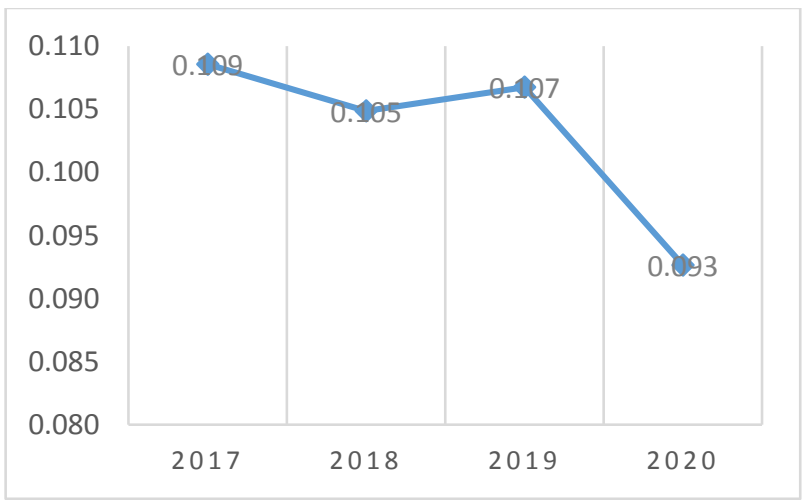

Grafik 5. X5 SATA

Dari kelima indikator yang dianalisa, yang menjadi perhatian adalah indikator X2 (Retained earnings to total asset - RETA) dan X3 (Earnings before interest and taxes to total asset - EBITTA). Kedua indikator ini mengalami rasio perubahan yang cukup besar yaitu RETA $-49,1 \%$ dan EBITTA -42,4\%. Ini merupakan gambaran rasio pendapatan perusahaan yang secara signifikan mengalami penurunan. Tentu saya ini memberikan dampak yang cukup besar 
terhadap hasil perhitungan Z Score. Berikut adalah hasil Model Altman dengan menggunakan Z Score:

Tabel 2

Hasil Perhitungan Z Score

\begin{tabular}{lcccc}
\multicolumn{5}{c}{ Hasil Perhitungan Z Score } \\
\hline \multirow{2}{*}{ Indikator } & \multicolumn{4}{c}{ Tahun } \\
\cline { 2 - 5 } & 2017 & 2018 & 2019 & 2020 \\
\hline WCTA & 0,220 & 0,235 & 0,241 & 0,217 \\
RETA & 2,572 & 2,495 & 2,426 & 1,234 \\
EBITTA & 0,033 & 0,032 & 0,031 & 0,018 \\
MVEBVD & 0,369 & 0,366 & 0,422 & 0,323 \\
RETA & 0,109 & 0,105 & 0,107 & 0,093 \\
\hline Z Score & 4,302 & 4,204 & 4,145 & 2,331 \\
\hline
\end{tabular}

Sumber: Data olahan 2021

Dari hasil olah data diatas dapat dilihat bahwa Nilai Z Score pada periode sebelum masa pandemic Covid-19 (tahun 2017 sampai dengan Tahun 2019) berada diatas ambang nilai cutoff 2,675 yang artinya kondisi perusahaan berada pada zona sehat. Namun pada Tahun 2020, yang menjadi awal periode terjadinya pandemic covid-19 nilai $\mathrm{Z}$ score nya berada di wilayah cutoff antara batas bawah 1,81 dan batas atas 2,675 $(1,81<2,331<2,675)$ yang berada pada grey area. Meskipun kondisi ini tidak sampai membuat perusahaan berada pada kondisi yang berpotensi pada kebangkrutan, tetap saja hal ini harus menjadi perhatian.

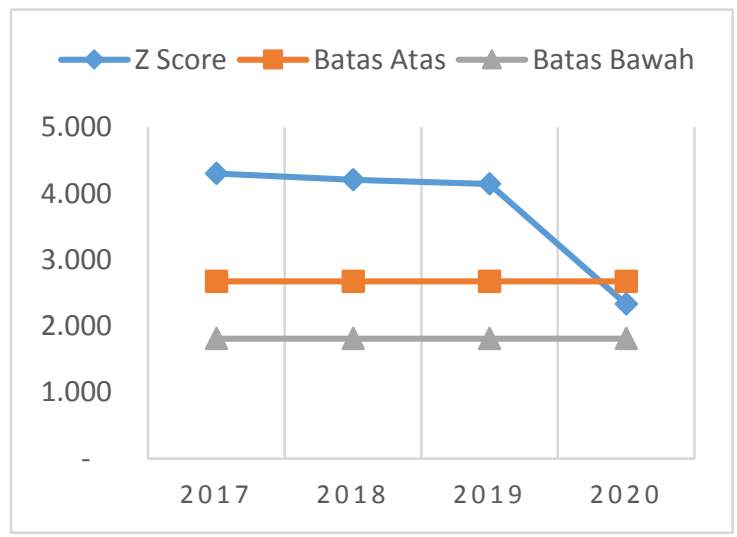

Grafik X. Nilai Altman Z Score

Grafik diatas memberikan gambaran lebih jelas bagaimana perubahan perilaku kinerja keuangan PT. Bank Rakyat Indonesia (Persero)Tbk. sebelum dan pada masa terjadinya pandemic Covid-19. Terjadi penurunan kinerja keuangan yang sangat signifikan pada tahun 2020 yang membawa perusahaan berada pada grey area.

\section{KESIMPULAN DAN SARAN}

Penelitian ini bertujuan untuk melihat posisi keuangan perusahaan dinilai dari pendekatan Financial DistressPrediction dan menggunakan model penilaian Z Score Altman Model. Analisa data dilakukan pada masa pandemic covid-19 (2020) dan sebelum (2017-2019). Pandemic Covid-19 yang 7 terjadi terutama di Indonesia memberikan dampak yang tidak baik bagi kinerja PT. Bank Rakyat Indonesia (Persero)Tbk. Perubahan signifikan yang terjadi atas nilai Altman Z Score dalam penelitian ini memberikan gambaran bahwa perusahaan yang sebelumnya terklasifikasi sehat (sebelum pandemic Covid-19) mengalami penurunan ke grey area (tahun 2020). Meski jika dilihat secara parsial atas indikator-indikator utama keuangan perusahaan baik-baik saja, namun perubahan ini harus menjadi perhatian kedepan terlebih sampai dengan penelitian ini selesai dilakukan Pandemi Covid-19 juga belum selesai.

\section{DAFTAR PUSTAKA}

Altman, E.I., 1968. Financial ratios, discriminant analysis and the prediction of corporate bankruptcy, The Journal of Finance, vol. 23.

Ardiyanto, F. D. dan P. Prasetiono. 2011, Prediksi Rasio Keuangan Terhadap Kondisi Financial distress Perusahaan Manufaktur Yang Terdaftar di Bursa Efek Indonesia. Jurnal Dinamika Ekonomi \& Bisnis, 8 (1), 1-14.

Atmini, S., dan Wuryana. 2005. Manfaat Laba dan Arus Kas untuk Memprediksi Kondisi Financial Distress Pada Perusahaan Textile Mill dan Products and Apparel and Other Textile Products yang Terdaftar di Bursa Efek Jakarta. Simposium Nasional Akuntansi VII: $460-474$.

Beaver, W. H. 1966. Financial ratios as predictors of failure, Journal of Accounting Research (Supplement), vol. 4.

Cahyaningrum, N. H. dan A. M. Haryanto. 2012. Analisis Manfaat Rasio Keuangan dalam Memprediksi Pertumbuhan Laba (Studi Kasus: Perusahaan Manufaktur yang terdaftar di Bursa Efek Indonesia periode 2005 sampai dengan 2010). Disertasi Doktoral, Universitas Diponegoro.

Cao, Y. Wan, G. Wang, F. 2011. Predicting financial distress of Chinese listed companies using rough set theory and support vector machine, Asia-Pacific Journal of Operational Research, vol. 28, no. 1. 
Darsono dan Ashari. 2010. Pedoman Praktis Memahami Laporan Keuangan. Penerbit Andi. Yogyakarta.

Gunawan, B. Pamungkas, R. Susilawati, D. 2017. Perbandingan Prediksi Financial Distress dengan Model Altman, Grover dan Zmijewski, Jurnal Akuntansi dan Investasi, 18 (1), 119-127.

Martin, D. 1977. Early warning of bank failure. A logit regression approach, Journal of Banking and Finance, vol. 1, no. 3.

Maryati, H. dan I. Zulkarnain. 2014. Analis Prediksi Financial distress Dengan Menggunakan Model Z-Score (Altman) (Studi Kasus Pt. Indocement Tunggal Prakarsa, Tbk Yang Terdaftar Di Bursa Efek Indonesia Periode 2007-2012). Disertasi Doktoral, Universitas Bengkulu.

Munawir. S. 2014. Analisis Laporan Keuangan, Edisi Kedua, Cetakan Kelima Belas, Penerbit Liberty, Yogyakarta.

Ohlson, J.A. 1980. Financial ratios and the probabilistic prediction of bankruptcy, Journal of Accounting Research, vol. 18 , no. 1.

Park, C. Han, I. 2002. A case-based reasoning with the feature weights derived by analytic hierarchy process for bankruptcy prediction, Expert Systems with Applications, vol. 23, no. 3.

Platt, H.D. Platt, M.B. 2002. Predicting Corporate Financial Distress: Reflection and ChoiceBase Sample Bias. Journal Economic and Finance, 26 (2), 184-199.

Rahmat, D. 2019. Profitability Index dalam Financial Distress Mitigation Studi pada Bank BUMN di Indonesia. Jurnal Integra Sekolah Tinggi Ilmu Ekonomi Indonesia Pontianak. Vol.9. No.2.

Shin, K. Lee, T. S. Kim, H. 2005. An application of support vector machines in bankruptcy prediction model, Expert Systems with Applications, vol. 28, no. 1.

Sun, J. He, K. Li, H. 2011. SFFS-PC-NN optimized by genetic algorithm for dynamic prediction of financial distress with longitudinal data streams, Knowledge-Based Systems, vol. 24, no. 7.

Wulandari, V. 2014. Analisis Perbandingan Model Altman, Springate, Ohlson, Fulmer, CAScore dan Zmijewski Dalam Memprediksi Financial distress (studi empiris pada Perusahaan Food and Beverages yang Terdaftar di Bursa Efek Indonesia Periode 2010-2012). Jurnal Online Mahasiswa (JOM) Bidang Ilmu Ekonomi, 1 (2), 1-18. 